Marianne Presthus Heggen is Associate Professor at the Western Norway University of Applied Sciences (HVL). She is an ecologist and teaches natural science, outdoor and environmental education in early childhood teacher education. Together with her team, she has developed the course "Sustainable Development through Involvement". Her research focus on the field of education for sustainability in early childhood. She leads the research group Education for Sustainability and Being and Becoming Eco-Citizens, at KINDknow - Kindergarten Knowledge Centre for Systemic Research on Diversity and Sustainable Futures.

Barbara Maria Sageidet is Associate Professor at the University of Stavanger. She has a research focus on sustainability, science education, and inquiry learning in early childhood education, and is part of the 'KINDknow' - Kindergarten Knowledge Centre for Systemic Research on Diversity and Sustainable Futures. Her background and PhD are related to botany, ecology, paleoecology and soil sciences. Since 2010, she is an active member of the international research group 'Transnational Dialogues in Research in Early Childhood Education for Sustainability (TND)'.

Nina Goga is Professor of children's literature at the Western Norway University of Applied Sciences. Research interests: Children's literature, ecocriticism, ecodidactics, place/space studies. Her most recent books are Ecocritical Perspectives on Children's Texts and Cultures: Nordic Dialogues (2018, co-edited with Lykke GuanioUluru, Bjørg Oddrun Hallås and Aslaug Nyrnes) and Maps and Mapping in Children's Literature. Landscapes, seascapes and cityscapes (2017, co-edited with Bettina Kümmerling-Meibauer). She is part of the work package "Being and becoming eco-citizens" at KINDknow - Kindergarten Knowledge Centre for Systemic Research on Diversity and Sustainable Futures.

Liv Torunn Grindheim is Associate Professor at Western Norway University of Applied Sciences, and a part of KINDknow - Kindergarten Knowledge Centre for Systemic Research on Diversity and Sustainable Futures. She has long experiences as an early childhood teacher, and a PhD from 2014 on 'The everyday life of child-citizens, a study on children's participation in three Norwegian kindergartens'. Her research interests are ECE as an arena for democratic formation and sustainable development, play, and early childhood teacher education.

Veronica Bergan is Associate Professor on the pre-school teacher education program at The Arctic University of Norway and emphasize on out-door pedagogy for a sustainable future. Research interests are active and social learning through regenerative farming and vegetable garden activities. Key elements to her teaching and research approach are the aspect of embodied and emplaced learning in nature. She is part of the work package "Being and becoming eco-citizens" at KINDknow - Kindergarten Knowledge Centre for Systemic Research on Diversity and Sustainable Futures.

Inger Wallem Krempig is Associate Professor at The Arctic University of Norway (UiT). She teaches science, health, and physical education on different levels in early childhood teacher education, and in outdoor education. Her research interest is on children in nature, with a special focus on food resources in kindergartens. She has published scientific articles, journal articles, books and TV-programs related to children and nature. She is associated to the work package "Being and becoming eco-citizens" at KINDknow - Kindergarten Knowledge Centre for Systemic Research on Diversity and Sustainable Futures.

Tove Aagnes Utsi is Associate Professor at The Arctic University of Norway (UiT). She is a biologist and teaches in natural science and natural resource use in the early childhood teacher education. The research interest is on biological resources and ecosystem services with focusing on education and food resources for animals and humans. She has published science in the field of biology and related to the kindergarten. She is part of the work package "Being and becoming eco-citizens" at KINDknow - Kindergarten Knowledge Centre for Systemic Research on Diversity and Sustainable Futures.

Anne Myklebust Lynngård, is Assistant Professor at Western Norway University of Applied Sciences at Western Norway University of Applied Sciences. She is an ecologist and an experienced teacher in early childhood teacher education on topics in natural sciences and outdoor learning. Her research foci are on how preschools are working with natural science in nature, with a particular interest in harvesting and farming activities as learning activities. She is part of the work package "Being and becoming eco-citizens" at KINDknow - Kindergarten Knowledge Centre for Systemic Research on Diversity and Sustainable Futures. 


\title{
Children as eco-citizens?
}

\begin{abstract}
Education for sustainability in early childhood tends to focus on practices and advocacy, rather than on the aims of this education. We suggest that the aim should be to consider children as being and becoming eco-citizens. This suggestion is built on an exploration of children as eco-citizens. With theories concerning child-sized citizenship we suggest a description of children and adults as being and becoming ecocitizen. We explore this through the fields of nature connection and science and children's curiosity. We find that environmentally friendly practices as gardening and harvesting wild food show how children's eco-citizenship is realizable. We support this additionally by references to how children's literature, seeing how children depicted as eco-citizens can support the notion of children as eco-citizens. Through these analyses, we conclude that children should be viewed as being and becoming eco-citizens.
\end{abstract}

Children are the stakeholders and creators of the future and their role in the quest towards a more sustainable future is of particular importance (e.g. Samuelsson, 2011; Davis \& Elliott, 2014; SirajBlatchford, Mogharreban \& Park, 2016). Most of the research on early childhood education for sustainability (ECEfS) lies within interpretative research of practices or advocacy, on how or why we should work with education for sustainability (EfS) in early childhood education (ECE) (Somerville \& Williams, 2015). In order to answer how ECEfS should be practiced, it is important to look at the aim of this education. What do we want to achieve with ECEfS?

The aim to establish children's connection with nature is still one of the large discourses in ECEfS (Somerville \& Williams, 2015). However, ECEfS, and the concept of sustainability itself, could be criticised for its anthropocentric perspective. It has been argued that, in order to achieve a change towards a more sustainable and equal community, our view of nature should be eco-centric rather than anthropocentric (Vetlesen, 2015). An eco-centric educational approach emphasize the goal to give children an emerging understanding of humans as parts of the diverse life on Earth, and that solidarity and care for the more-than-human world is necessary (Næss, 1976; Taylor \& Pacini-Ketchabaw, 2015; Weldemariam, 2017). This should influence the way we work with environmental issues in ECE (Dickinson, 2013).

A change from an anthropocentric to an eco-centric view of nature is harmonizing with a change from an adult centric view of children to a more child centric understanding of children. This transition depicts children as important contributors in their everyday lives (James, 2009; Robson, Bell \& Klocker, 2007), also when being children - not only as becoming adults. Children that are not yet socialised into an established understanding of the relationship between nature and humans may challenge established anthropocentric solutions for EfS. Using the term eco-citizens as it comes to children, acknowledges that children have experiences only they know, that are of relevance for the society. 
We suggest an ECEfS grounded on multidimensional perspectives of environmental challenges with an aim to view children as competent agents in their own lives. In this context, we elaborate the concept of children as eco-citizens and suggest that ECEfS aims to realize children as both being and becoming eco-citizens.

\section{METHODOLOGY}

This theoretical study aims to explore the concept of children as being and becoming eco-citizens by help of interdisciplinary inquiry (Derry, Schunn \& Gernsbacher, 2014). Interdisciplinary inquiry integrates concepts, philosophies and methodologies from different fields of knowledge. It crosses disciplines and engages participants in collaborative dialogue, which both transforms the understanding of individual participants, and produces new knowledge and new solutions (Klein, 2014).

In our work, we outline an understanding of the concepts child sized citizenship and child sized ecocitizenship. Then we move on to explore the relationships between child-sized eco-citizenship and relevant discourses of early childhood; children's connection with nature and science and children's curiosity. With these in mind, we explore the potential for a focus on eco-citizenship in activities in Norwegian ECE related to gardening and harvesting activities. We also investigate how children's literature may contribute to position and empower children as eco-citizens.

Based on the outline on child sized citizenship and eco-citizenship, and in light of contrasting and complementary fields, this study explore the following research question: How may perspectives of nature and science, curiosity, gardening, harvesting, and children's literature within ECEfS contribute to realize children as active agents, as both being and becoming eco-citizens?

\section{CHILD SIZED CITIZENSHIP AND ECO-CITIZENSHIP}

Citizenship is a complex, disputed and theoretical concept especially within political, pedagogical and philosophical theory. In this article, we are in line with the contemporary discussion that relate the concept citizenship to children's belonging, participation and cooperation in a group, a community or a society (Bjerke, 2012). Children's citizenship is relevant in educational contexts and practices like ECE (Barr, 2005; Grindheim, 2015; Kjørholt, 2008; UNESCO, 2014). The English concept 'citizenship' refers to both citizenship as status and citizenship as role (Ødegaard, 2012). According to children's legal rights they have status as citizens (UNCRC, 1989). They also have a role as citizens in the society, where they attend as public persons and not only as a part of their family, as in their attendance in the public sphere like ECE.

Children are however not entitled to participate in the society by voting at official elections. Rather, the way they perform their rights are within the constituted conditions to participate, close to 'citizenship as role' or as 'citizenship as practice' (Lister, 2003). Children having status and role as citizens form a contrast to traditional theories of citizenship where children were seen as citizens 'in potentia' (Marshall, 1950). Therefore, children's formal rights challenge the traditional understanding of democratic citizens, which is based on rationality, autonomy and the right to vote (Cockburn, 1998).

Educational contexts often emphasise children's learning from the perspective of them becoming citizens, but ECE centres are not just places for future citizens to develop. They are places where children stay and live, as children. Research has delineated an adult-centred understanding of where and how children can contribute and where and how their legal rights are exercised, which may not accord with how children participate, inhabit, negotiate and challenge the established community (Cockburn, 1998; James, 2011; Liebel, 2008; Seland, 2009). In order to welcome children's contribution to reach the aims of EfS, it is of interest to explore their 'citizenship as practice' (Lister, 2008), the way children exercise their rights within the established conditions in ECE. Using the concept citizenship 
in accordance with children, legitimizes children as different citizens and as important contributors with unique perspectives that can be of interest when meeting contemporary challenges as EfS.

Valuing children's perspectives and contributions are in line with the emphasis on children as agents of change achieved in transactions (Caiman \& Lundegård, 2014). It also helps to curb the pastoral power that children often are met with when education for sustainability is limited to reconstruct knowledge from the grown-up generation. Our concern is that the problems that already exist are reconstructed by knitting together personal guilt with global threats in detailed individual activities for rescuing humans and planet as suggested by Ideland and Malmberg (2015).

Children are not adults, and are hence 'different' citizens (Lister, 2008), living a 'child-sized' citizenship (Jans, 2004, p.38). They are not fully responsible of their own actions nor at all responsible of contemporary problems. Children are more dependent on caretakers than adults are, their immaturity is biological, they have less experience and play is a more common way of interacting among children than among adults (Jans, 2004). Although children should learn to see the consequences of their actions (e.g. Ministry of Education and Research, 2005), accepting children as different citizens include understanding that it is the responsibility of adults to meet children's contributions and to decide what to take into consideration. Adults are also responsible to share earlier generations' experiences and cultural tools.

The shift from an adult centred view of citizenship opens up for recognizing both differences and similarities between children and adults. It also opens up for different forms of participation that can contribute to meet the problems of sustainability, in both formal and informal settings (Biesta, Lawy \& Kelly, 2009; Cockburn, 1998), and in day-to-day activities that links local and global understanding, including informal settings like play (Grindheim, 2017). In play, children create an imaginative space where their experiences and problems are investigated and where they produce something new (Caiman \& Lundegård, 2014). These may be valuable ways of meeting the future problems of sustainability, problems that calls for new solutions.

In education, there are value based aims for what we want for the next generation. Both children and adults change from influences by their surroundings, personal interests and urge to understand. In a rapidly changing world, we all have to adopt to new challenges and new technology, and are hence being and becoming citizens both as children and as adults.

\section{From child sized citizenship to child sized eco-citizenship}

In Nordic ECE children can practice their citizenship through daily activities, often as play in nature (Aasen, Grindheim \& Waters, 2009). How this play influence children is dependent on how children, and we, think of nature (Dickinson, 2013). Viewing nature as a source for services or commodities, an anthropocentric view of nature, may increase the problems, while viewing nature as equal and valuable in itself, an eco-centric view of nature, may be necessary in EfS (Vetlesen, 2015; Goga, GuanioUluru, Hallås \& Nyrnes, 2018). This brings us to child sized eco-citizenship. Eco-citizenship seems to include a stronger inclusion of the more-than-human parts of the world's ecosystem (Dean, 2001; Barr, 2005).

The idea of global citizenship has emerged along with the ecological concerns for our planet, and international guiding documents like Our common future (WCED, 1987). These documents state that global citizenship education depend on a society open to universal values, with transformative learning and through the empowerment of youth (Barr, 2005; UNESCO, 2014). The UN decade for education for sustainable development made 'Global Citizenship Education' as the framing paradigm (UNESCO, 2014). Global citizenship is a holistic approach with focus on open, democratic and respectful communication, on value formation and on critical thinking. Yet, UNESCO (2014) acknowledges that a term like 'planetary citizenship' might be a better focus on the global community's responsibility to preserve the planet Earth. 
We suggest the term eco-citizen, a term without finalized definitions, or clarified connections to small children, although the presented documents may be understood as giving also children a role as being eco-citizens. Eco-citizens practice their citizenship on planet earth, participating in the ecological system of the planet, together with the more-than-human world (UNEP, 1975; Næss, 1976; Newby, 2016; van Steenberger, 1994; Dean, 2001; UNESCO, 2015). Eco-citizens have a common and individual responsibility for the planet, all its inhabitants, and future generations. Both adult-sized and childsized eco-citizens have additional rights that provide for the protection of the individual against the effects of pollution and environmental degradation. We understand children as eco-citizens practicing a child sized eco-citizenship by their involvement in their local community and their local nature.

\section{NATURE CONNECTION AND SCIENCE}

Working with EfS with young children is often seen as controversial, and the importance of the innocent childhood is often emphasized (Wals, 2012). The Nordic countries have a long tradition of using nature and outdoor areas as a resource for the work of social competence, sustainable development, and belonging (Braute \& Bang, 1994; Aasen, Grindheim \& Waters, 2009; Caiman, 2015; Sageidet, 2015; Heggen, 2016). The innocent quality of nature encounters may meet the demands to combine EfS with the concept of an innocent childhood. In models of environmental identity development, children's environmental development is depicted as a development from the connection with nature, through experiences and knowledge to identification and responsibility for the environment (Blanchet-Cohen, 2008; Green, Kalvaitis \& Worster, 2016; Langholm, Hilmo, Holter, Lea \& Synnes, 2017). Experiences in nature are explicitly considered valuable in bridging the human-nature divide, and Dickinson (2016) suggests that nature and children can overcome this dichotomy through eco-cultural conversations where nature is given an active voice with a focus on the presence of nature, as a dead mice, a climbing squirrel, etc,. It has also been argued that special places in nature where children have positive experiences of exploratory play, hike, camping or fishing, are considered of great importance for their ecological engagement as adults (Chawla, 2006; 2007; Vadala, Bixler \& James, 2007). Interrelationships in nature that are experienced and explored locally in ECE apply to global systems, suggesting a potential for the formation of children as eco-citizens. Pre-school children familiar with play in nature can view nature in both anthropocentric and eco-centric perspectives (Hallås \& Heggen, 2018). However, many children do not have access to un-organized nature, and rapid urbanization result in nature related experiences to occur in urban areas for a majority of the world's children (Sageidet, Almeida \& Dunkley, 2018).

Although nature experiences, in more or less wild areas, may provide children with opportunities, skills and perceptions to develop as eco-citizens, nature experiences in themselves are not enough. The influence of nature experiences is dependent on how children view nature (Dickinson, 2013). Through interaction with competent adults, children may learn about natural phenomena and complex relationships in nature (e.g. Fleer, 2015; Hatch, 2010). Other studies also suggest that adult role models showing the value of the natural world through their own appreciative attention are important for developing ecological attitudes (Chawla, 2007).

Recognising a world that is becoming increasingly complex, Elmose and Roth (2005) underline the importance of science education as a contribution to children's ability to live responsible. Inquiry based outdoor activities (Sageidet, 2012; Sundberg \& Ottander, 2014) acknowledge mutual learning between children and adults, and children's attention may be drawn to interrelations and analogues between the physical world and ecological relations, the human body and social relations in the environment (Aasen, 2006). The children may also draw the adult's attention towards objects or issues they overlook, and contribute to the adults becoming eco-citizens (Utsi, Bøe \& Krempig, 2019). ECE teachers can build on the eco-citizenship concept by continuously linking concrete local examples and activities to global or more abstract interrelations. 


\section{CHILDREN'S CURIOSITY}

Recognizing, supporting and helping children's curiosity is about the child's right to participate as a child, being an eco-citizen and developing themselves as becoming eco-citizens. Curiosity is valued as an important and desirable attribute of EfS (Kasin, Haugen, Langholm, Heggen \& Syed, 2019), and children's opportunity to wonder was underlined already when children were introduced into environmental citizenship (Carson, 1965/1998). Natural science in Norwegian ECE is often based on children's curiosity. It is expected that children will begin to develop knowledge and understandings about processes and contexts in nature through their curiosity (Norwegian Directorate for Education and Training, 2017).

Children's curiosity and involvement are correlated, and the more curious a child is, the longer the child is engaged in a situation (Jirout \& Klahr, 2012; Gruber, Gelman \&Ranganath, 2014 ). Ranganath, 2014). There are also reasons to believe that engagement and curiosity lead to more knowledge and insight, leading to more curiosity. Motivation and engagement also increase when children develop knowledge (Patrick \& Mantzicopoulos, 2015). There is hence a close link between curiosity, motivation and engagement.

No exact definition of curiosity exists (Jirout \& Klahr, 2012) and there is little research on the nature of curiosity (Gruber, Gelman \& Ranghanath, 2014). Humans are however assumed to be born curious and curiosity is considered a positive feature in most contexts. Some children may however be more naturally curious than others (Cohen, Schoene-Bake, Elger \& Weber, 2009; Gruber, Gelman \& Ranganath, 2014). While there are no criteria for measuring curiosity, it is often thought to be verified by questioning; the more questions, the more curious a child is perceived (Jirout \& Klahr, 2012; Patrick \& Mantzicopoulos, 2015). Curiosity is also described as something that leads to exploratory behaviour as touching or collecting (Jirout \& Klahr, 2012). These less perceptible signs of curiosity may require specific attention by pre-school teachers.

ECE teachers play an important role in conditioning children's curiosity, explorative behaviour and understanding of nature (Caiman \& Lundegård, 2014). Research on how to influence children's curiosity is however scarce (Cohen et al., 2009). It is believed that children who receive many impulses from the environment may expand their curiosity (Cohen et al., 2009). Also, when children and adults have a common commitment and share their thoughts, the conversations last longer (SirajBlatchford, 2009). Such conversations can lead to increased involvement and learning outcomes, but knowledge of how to do this is needed (Gustavson \& Pramling, 2014). Studies have shown that preschool teachers too seldom support children's scientific thinking or help them to see relationships in nature (e.g. Ejbye-Ernst, 2012). Other reports that children rarely get scientific answers to their questions in pre-school (Thulin, 2011). This may lead to the children ceasing to ask questions, thus being perceived as less curious. Lindholm (2018) suggest that children's capaicity for more philosophical wonder should be stimulated in early childhood to increase curiosity later in life.

Curiosity and exploration are important aspects in envisioning a more sustainable future (Corcoran, Weakland \& Wals, 2017). As we have seen, curiosity, engagement and motivation are linked and the learner's engagement and motivation are crucial for eco-citizens to develop their own environmental philosophy (Næss \& Jickling, 2000). Children's curiosity lifts themes children are engaged in, sustaining and stimulating curiosity in ECE can be seen as an element in democratic participation (Menning, 2017). To support children as eco-citizens, we need a better understanding of how curiosity can be recognized, expressed and supported and how children and adults may nurture their mutual contributions to facilitate children as being and becoming eco-citizens.

\section{GARDENING AND HARVEST ACTIVITIES}

As the global population urbanizes, fewer children have opportunities to learn about the origins of food (Sageidet et al., 2018). Modern citizens can learn and experience how sustainable food can be 
grown or harvested locally to discover the interrelationships of nature (UNCTAD, 2013), and thus embody the notion of being and becoming eco-citizens regarding food choices (Krempig \& Utsi, 2017; Bergan, 2019). We will next explore how garden and harvesting activities can be of value in early childhood and elaborate how this can contribute to eco-citizenship.

\section{Gardening}

School gardening has a long tradition as an outdoor activity with the aim to educate children about food, nature and the environment (Blair, 2009; Ozer, 2007). The word "kindergarten" originates from Friedrich Fröbel (Herrington, 1998), and recognizes the importance of play and garden activities in learning. The garden represents a metaphor for children, where the teacher/gardener supports the children's formative development and growth (Herrington, 1998). What children see, practice and learn in early childhood, may stay with them as values and habits through their whole life.

Gardening is a recurrent and habitual practice in which the teachers facilitate and are role-models of eco-citizenship (Bergan, 2019). For children to be and become eco-citizens we need holistic perspectives, knowledge and skills that enable them to engage in sustainable practices. Organic gardening is a direct and local action that influences the ecological, economic and socio-cultural dimension of sustainability. Organic methods may establish a close encounter with sustainable practices and promote diversity of life in the soil.

The increasing number of websites facilitating educational gardening and urban community gardening (e.g. BørnsByhaver, 2015; FarmToPreschool, 2011; Geitmyra, 2010) may suggest that gardenprojects in ECE are quite prevalent. It has also been suggested that children in urban areas may get access to nature experiences in small roadside or window-sill gardens (Sageidet et al., 2018). When children play and interact in a garden it often brings a feeling of happiness, and new discoveries may support children's curiosity and questions (Midden \& Chambers, 2000; Green \& Duhn, 2015). Through gardening, children may also explore the economic and socio-cultural aspects of sustainability; selling their harvest, playing "food shop", reusing materials, collective and active ownership, and planning activity in the garden (McCrea, 2015; Miller, 2007). Gardening may also trigger children's agency, achieve action competence and creativity to envision sustainable solutions (Caiman \& Lundegård, 2014). Agency is particularly evident when children participate with an emancipatory approach (Cincera et al., 2017; McLennan, 2010).

Bartnæs and Bergan (2018) studied organic gardening as a place-based learning process. The aim of the study was to look at the ECE teacher's role, and the findings suggest that adults walking beside the child to interact with garden beds, tools and plants, pointing out clues of information along the way is important. Such wayfaring requires direct transferring of plant knowledge through education of attention, fine tuning of perceptional skills and atonement to the child's level of understanding (Ingold, 2010).

\section{Harvesting wild food resources}

Harvesting is a part of the traditional use of nature, especially where there has been, or still is, huntergatherer cultures (Lew-Levy, Reckin, Lavi, Cristóbal-Azkarate, Ellis-Davies, 2017; Łuczaj et al., 2012). In Norway, harvesting activities are considered a part of the outdoor traditions and of importance for the development of children's nature contact and knowledge (Ministry of Climate and Environment, 2016). Wild food resources are accessible for many ECE centres, both in rural and urban areas. Like gardening, local harvesting give experiences that influence sustainability holistically, including the consumer part of the food web. The children get direct experiences with nature and the food chain when they participate in harvesting, cooking and eating as shown in an ECE centre in northern Norway (Krempig \& Utsi, 2017). The children and staff spent considerable time together in nature, exploring nature in playful and curiosity driven activities. Such experiences can be compared with cultures in hunter-gathering societies (Gray, 2009) which create human-nature relations, social bands and promote sharing and equity, important values and practices as eco-citizens. However, the adult's at- 
titudes and influence are central for implementation of harvesting activities in kindergartens (Nuget \& Beames, 2015). The study by Krempig and Utsi (2017) showed how harvesting combined children's scientific and social learning in nature. The involved children expressed interest and engagement both throughout the harvesting processes and when performing spontaneous or planned studies of plants and animals. Their engagement was expressed both verbally and physically. Supported by the teachers, the children discussed biology of the harvested organisms, ethics of hunting, and diversity of food resources in natural areas. They investigated the products with questioning and touching, activities that are commonly connected to curiosity (Jirout \& Klahr, 2012, Patrick \& Mantzicopoulos, 2015). As stated earlier, such curiosity may support a development of connection to nature and a growing understanding of the complexity of ecosystems, and might lead to an eco-centric view of nature. This suggests that through harvesting, children might explore and experience local nature and learn different ways of sustainable resource use. Introducing such science inquiry skills while exploring nature contribute to empower children (Sundberg \& Ottander, 2014), also as eco-citizens. Utsi, Bøe and Krempig (2019) highlight the social dimension in children's and adult's learning outcomes of a harvesting project. While an engaged and competent companion in nature might stimulate children's future environmental engagement (Chawla, 2007; Thulin, 2011), Utsi, Bøe and Krempig (2019) show how the children also contributed to increasing the adult's knowledge base. We understand this as one of the ways these children perform their eco-citizenship.

Harvesting wild food resources might initiate a variety of nature experiences in early childhood, supporting inquiry-based learning and give insight into natural cycles. The socio-cultural dimension is evident in traditional harvesting activities and the social aspect of harvesting is expected to enhance the learning outcome. The potential for children to also explore the economic dimension of sustainability through harvesting lays in the use of the self-collected resources in different dishes or making food products for gifts and sale. Harvesting activities might support long-term learning and sustainable education for young children, facilitating being and becoming eco-citizens.

In the harvesting- and gardening-projects we have explored, both children and teachers experienced a variety of natural food resources. By closely exploring the food resources and the path from the field or the forest to the table, they may have developed an interest for and understanding of the origin of food. Both children and teachers increased their awareness and enjoyment of for example fresh vegetables and fish, and through this expressed an enhanced preference for local food. Simultaneously, they explored and learned about different species, and they communicated these experiences (Bergan, 2019; Krempig \& Utsi, 2017; Utsi, Bøe \& Krempig, 2019).

\section{CHILDREN'S LITERATURE}

How the concept of eco-citizens is understood and operationalized within academic research on children's literature depends on whether one examine how children are characterised as eco-citizens in the texts, or how texts address or position the child readers as potential eco-citizens.

The Australian research community on teacher education and children's literature has proved to be the most academic comprehensive in examining the possible connection between children's literature and children's role as eco-citizens. They have developed a data basis including Children's Literature and the Environment, identifying works for children that deal with the environment in imaginative, scientific, educational, and creative ways. It includes scholarly texts and references.

Massey (2009) examine "how a representative sample of Australian texts [...] constructs fictional ecological subjects in the texts, and offers readers ecological subject positions inscribed with the contemporary environmental ideologies" (p. iii). One may here understand the concept of 'ecological subject' as a kindred concept to that of eco-citizens. Massey identifies three "ideologically grounded positions that humans may assume when engaging with the environment” (p. iii). While the first two positions are labelled unrestrained anthropocentrism and restrained anthropocentrism, the third 
is labelled ecocentrism (p. iii). This third position is perhaps the one that offers readers a position as an ecological subject or as an eco-citizen since it takes "a holistic approach to the recognition of the interconnectedness of all life forms and the physical elements of the environment” (p. 26).

According to Massey and Bradford (2011), one of the primary functions of children's environmental literature "is to socialize young people into becoming the responsible and empathetic adults of tomorrow by positioning readers as eco-citizens, dedicated both to sustainable development in the local sphere and also to global responsibility" (p. 109). Even though Massey and Bradford make use of the concept of eco-citizens, they do not offer a clear-cut definition. They suggest that children's environmental literature may attempt "to enlist readers in taking action, encouraging them to reflect on the world as it is, and to imagine future scenarios if environmental degradation proceeds unabated" (p. 110). One may interfere that to reflect on the world as it is, and to imagine future scenarios could be part of eco-citizens obligations (e.g. Næss \& Jickling, 2000; Wals, 2012). Massey (2014) discuss how picturebooks construct children, both the characters and the readers, as responsible for sustainable futures, how the books didactically appeal to "children's sense of themselves as ecocitizens" (p. 27), and how verbal and visual narratives "create positions as eco-participants for child characters and readers" (p. 39). Once more eco-citizens may be exchanged with another concept, this time with 'ecoparticipants'.

The final contribution to the topic of children's literature and eco-citizenship is an article (Goga, 2017) on how picturebooks may help readers to connect, combine and relate their aesthetic reading experiences to outdoor activities, and, through this interrelation, develop or strengthen a connection to nature needed to become an eco-citizen. In this study, Goga found that one of the analysed picturebooks depicted its characters as eco-citizens, meaning, "problematizing their surroundings and displaying an agency of their own" (Goga, 2017, p. 94). In addition, readers are invited to adopt the eco-centric position of the characters. Such a position may encourage the child reader to take action and question the sustainability of, and actively the involvement in, their local community and nature. This view is hence in line with the conception of a child sized eco-citizenship.

\section{HOW CAN CHILDREN BE REALIZED AS BEING AND BECOMING ECO-CITIZENS?}

In this paper, our focus is on children's potential role as being and becoming eco-citizens. We will discuss the examples and their implications for the two aspects separately, before we investigate the consequences and possibilities for ECEfS.

\section{Being eco-citizens}

Children have legal rights as citizens (UNCRC, 1989), but the majority of our examples refer to different aspects of citizenship as a role, the way the children exercise their rights. We recognize children as different citizens, with different ways of participation, different responsibilities, and different contributions than adults. Children's participation through play and agency, the way they perform their ecocitizenship will differ from adult's engagement. This might reveal both possibilities and challenges when considering children as being eco-citizens.

Adults are responsible to support children's participation by providing tools and teaching skills. They are responsible to share earlier generations' experiences and knowledge, as when they communicate and wonder with the children or act as wayfarers in harvesting and gardening activities. At the same time, it is also the adult's responsibility to meet the children's attention to obstacles and to encourage the children to find sustainable solutions without interfering with their adult views (Caiman \& Lundegård, 2014). This increase the importance of children's social belonging.

In gardening and harvesting situations, the children are active participants of a socio-cultural tradition. Spending considerable time together in nature, the adults and children in the pre-schools bound together in community, culture and place. The adults' role here may be to convey important 
knowledge as on which species we may eat or cultivate, cultivation techniques or hunting strategies. Children's contributions as different eco-citizens may be innovative ideas to try different species, to initiate exploration of new cultivation techniques, new ways to use land-areas or how we may share crops. Children may also increase the staff's competence through their contribution in gardening and harvesting activities (Bergan, 2019; Utsi, Bøe \& Krempig, 2019). There are however limitations also to these contributions. Some species are not edible, and there are diverse ways to set potatoes or sow carrots that give different yields and results.

Through mutual engagement in meaningful and recurrent activities meeting the human-nature interface, children and adults are active agents of learning and exploring. These activities could contribute to nature appreciation, an important motivator to sustainable actions and the act of taking care of the planet. In the outlined activities, adults and children are involved in collaborative processes, which may support key competences for sustainability as creative, complex and anticipatory thinking, systems thinking, action competence, and decision-making (Wiek, Withycombe \& Redman 2011, UNESCO 2017). Competences that are all important for eco-citizens.

The central role of play in children's eco-citizenship is repeatedly the focus in this article. Nature interactions and careful encounters with children's literature in play may let children explore and take responsibility, and play may hence create valuable ways of meeting the future problems of sustainability. When reading environmental literature, both children and adults may reflect on our world as eco-citizens. To meet in literature encounters may provide opportunities for children and adults to explore and reflect upon such values and aims of both oneself and each other. Reading about children portrayed as eco-citizens may provide a starting point for reflections on adults' and children's agency.

Accepting children as citizens with different contributions than adults involves acceptance of and support to children's agency and ideas. Children have relevant experiences only they know, and they are not yet fully socialized into the adults' views of the world. The children may support adults to become eco-citizens through their questions and curiosity, thus giving rise to new knowledge, solutions and ways of doing practice. This may provide a possibility to contribute with new solutions, possibly challenging regular views of EfS. However, children's eco-citizenship may also challenge adult's principles and methods through their curiosity and interaction. In these times of uncertainty, there is a huge challenge to meet deviating ideas: How can we convey values and knowledge, while still not knowing which solutions will be the best for the future?

\section{Becoming eco-citizens}

Children have traditionally been considered as becoming citizens, and although we consider children as being eco-citizens we also acknowledge them as becoming eco-citizens. Education often emphasize children's learning within perspectives of them as becoming citizens. UNESCO (2014) view the aim of education as developing knowledge, skills, values and attitudes that learners need for securing a world which is more just, peaceful, inclusive, healthy and sustainable. As we see here, learning is important for both being and becoming eco-citizens, and these aspects are often linked.

Children need holistic perspectives, knowledge and skills that enable them to engage in sustainable practices, such as production and harvesting local food. Their engagement in pre-school and the involvement of their parents may inspire to small garden projects at home or an enjoyment for local fishing or berry picking. The children may play an important part to disseminating such sustainable practices, e.g. in urban settings, and thus becoming eco-citizens through meaningful hands on situated learning that has been initiated in ECE.

Through exploration, play, mutual engagement and curiosity, in activities to connect with nature, in gardening or harvesting or through reading children's literature, adults and children may together build the competences of present and future eco-citizens. While this list could include other perspectives and aspects from other disciplines, all these aspects affect children as becoming eco-citizens. 
Facing new and partly unknown environmental challenges, both children and adults are learning to become eco-citizens.

\section{CHILDREN AS ECO-CITIZENS - A NEW AIM FOR ECEFS}

Children as being and becoming eco-citizens opens up a new line of thought on why and how we should work with EfS. We have shown that there is a prevalence of literature and practices of EfS focusing on children as becoming eco-citizens. We have however argued that it is of similar importance to view children as being eco-citizens.

Children with an active identity as eco-citizens may feel an initial sense of belonging to our common planet, including the more-than-human world. Knowing the value of participation, they may exercise and further develop a desire of care, solidarity, curiosity, and knowledge. This can promote children as active and informed members of a sustainable society. We argue that an identity as eco-citizen may provide an emerging understanding that humans, including each individual child, are active parts of the environment. In this perspective, our actions have consequences for the future.

We suggest that to consider children as both being and becoming eco-citizens should be recognized as one of the most important aims of ECEfS. Viewing children as being and becoming eco-citizens pave way for an openness and awareness of giving room to more than what we already know. While emphasising the responsibility of the adults, this openness may raise the unique perspectives children contribute to the contemporary challenges and help to find new and unexpected ways to proceed towards a more sustainable future.

\section{REFERENCES}

Barr, H. (2005). Towards a model of citizenship education. Coping with differences in definition. In C. White \& R. Openshaw (Eds.), Democracy at the crossroads: International perspectives on critical global citizenship education (pp. 55-74). New York: Lexington Books.

Bartnæs, P. \& Bergan, V. (2018). Dyrking som stedlig læring i barnehagen. In A. Myrstad, T. Sverdrup \& M. B. Helgesen (Eds.), Barn skaper sted - sted skaper barn (pp. 169-188). Bergen: Fagbokforlaget.

Bergan, V. (2019). Hvordan kan økologisk dyrking bidra til bevissthet for bærekraft? In V. Bergan \& K. E. W. Bjørndal (Eds.), Bærekraft i praksis i barnehagen (pp. 99-114). Oslo: Universitetsforlaget.

Biesta, G., Lawy, R. \& Kelly, N. (2009). Understanding young people’s citizenship learning in everyday life: The role of contexts, relationships and dispositions. Education, citizenship and social justice, 4(1), 5-24. doi: 10.1177/1746197908099374

Bjerke, H. (2012). Barns perspektiver på samfunnsborgerskap: kritiske refleksjoner om rettigheter, ansvar og deltakelse. (Doctoral Thesis). NTNU, Trondheim.

Blair, D. (2009). The Child in the Garden: An Evaluative Review of the Benefits of School Gardening. The Journal of Environmental Education, 4O(2), 15-38. doi: 10.3200/JOEE.40.2.15-38

Blanchet-Cohen, N. (2008). Taking a stance: child agency across the dimensions of early adolescents' environmental involvement. Environmental Education Research, 14(3), 257-272. doi: 10.1080/13504620802156496

BørnsByhaver (2015). Børns Byhaver. Planteliv i børneøjenhøjde. Retrieved from http://xn--brnsbyhaver-ggb.dk/

Braute, J. N. \& Bang, C. (1994). Bli med ut! Barn i naturen. Oslo: Universitetsforlaget.

Caiman, C. (2015). Naturvetenskap i tillblivelse: Barns meningsskapande kring biologisk mångfald och en hållbar framtid. (Doctoral Thesis). Stockholms universitet, Stockholm.

Caiman, C. \& Lundegård, I. (2014). Pre-school children's agency in learning for sustainable development. Environmental Education Research, 2O(4), 437-459, doi:10.1080/13504622.2013.812722 
Carson, R. L. (1965/1998). The sense of wonder. New York: HarperCollins Publishers, Inc. Chawla, L. (2006). Learning to love the natural world enough to protect it. Barn, 2, 57-78.

Chawla, L. (2007). Childhood experiences associated with care for the natural world: A theoretical framework for empirical results. Children, Youth \& Environments, 17(4), 144-170. doi: 10.7721/ chilyoutenvi.17.4.0144

Cincera, J., Kroufek, R., Simonova, P., Broukalova, L., Broukal, V. \& Skalík, J. (2017). Eco-school in kindergartens: the effects, interpretation, and implementation of a pilot program. Environmental Education Research, 23(7), 919-936. doi: 10.1080/13504622.2015.1076768

Cockburn, T. (1998). Children and Citizenship in Britain. A Case for a Socially Interdependent Model of Citizenship. Childhood, 5(1), 99-117. doi: 10.1177/0907568298005001007

Cohen, M. X., Schoene-Bake, J.-C., Elger, C. E. \& Weber, B. (2009). Connectivity-based segregation of the human striatum predicts personality characteristics. Nature Neuroscience, 12, 32-34. doi: 10.1515/nf-2009-0105

Corcoran, P. B., Weakland, J. P. \& Wals, A. E. (Eds.). (2017). Envisioning futures for environmental and sustainability education. Wageningen: Wageningen Academic Publishers.

Davis, J. \& Elliott, S. (Eds.). (2014). Research in early childhood education for sustainability: International perspectives and provocations. New York: Routledge.

Dean, H. (2001). Green Citizenship. Social Policy \& Administration 35(5), 490-505. doi: 10.1111/1467-9515.to1-1-00249

Derry, S., Schunn, C.D. \& Gernsbacher, M. A. (Eds.) (2014). Interdisciplinary Collaboration: An Emerging Cognitive Science. New York: Psychology Press.

Dickinson, E. (2013). The Misdiagnosis: Rethinking "Nature-deficit Disorder”. Environmental Communication 7(3), 315-335. doi: 10.1080/17524032.2013.802704

Dickinson, E. (2016). Ecocultural Conversations: Bridging the Human-Nature Divide through Connective Communication Practices. Southern Communication Journal 81(1), 32-48. doi: 10.1080/1041794X.2015.1065289

Ejbye-Ernst, N. (2012). Pædagogers formidling af naturen i naturbørnehaver. (Doctoral Thesis). Aarhus Universitet, København

Elmose, S. \& Roth, W. M. (2005). Allgemeinbildung. Readiness for living in a risk society. Jounal of Curriculum Studies 37(1), 11-34. doi: 10.1080/0022027041000229413

FarmToPreschool (2011). Farm to Preschool. Retrieved from http://www.farmtopreschool.org/

Fleer, M. (2015). How Preschools Environments Afford Science Learning. In M. Fleer \& N. Pramling (Eds.), A Cultural-Historical Study of Children Learning Science. Foregrounding Affective Imagination in Play-based Settings. (pp. 23-37). Dordrecht: Springer.

Geitmyra (2010). Geitmyra Matkultursenter for barn. Retrieved from https://www.geitmyra.no/ barnehage/

Goga, N. (2017). A feeling of nature in contemporary Norwegian picturebooks. Encyclopaideia, 21(49), 81-97. doi: 10.6092/issn.1825-8670/7605

Goga, N., Guanio-Uluru, L., Hallås, B. O. \& Nyrnes, A. (Eds.) (2018). Ecocritical Perspectives on Children's Texts and Cultures. Nordic Dialogues. Basingstoke: Palgrave Macmillan.

Green, C., Kalvaitis, D. \& Worster, A. (2016). Recontextualizing psychosocial development in young children: a model of environmental identity development. Environmental Education Research, 22(7), 1025-1048. doi: 10.1080/13504622.2015.1072136

Green, M. \& Duhn, I. (2015). The Force of Gardening: Investigating Children's Learning in a Food Garden. Australian Journal of Environmental Education 31(1), 60-73. doi: 10.1017/ aee.2014.45

Gray, P. (2009). Play as foundation for hunter-gatherer social existence. American Journal of Play, 1(4), 476-522.

Grindheim, L. T. (2015). Kvardagslivet til barneborgarar: Ein studie av barna si deltaking i tre norske barnehagar. (Doctoral Thesis), NTNU, Trondheim.

Grindheim, L. T. (2017). Children as playing citizens. European early childhood education research journal, 25(4), 624-636. doi: 10.1080/1350293X.2017.1331076 
Gruber, M. J., Gelman, B. D. \& Ranganath, C. (2014). States of Curiosity Modulate HippocampusDependent learning via the Dopaminergic Circuit. Neuron 84(2), 486-496. doi: 10.1016/j. neuron.2014.08.060

Gustavson, L. \& Pramling, N. (2014). The educational nature of various ways teachers communicate with children about natural phenomena. International Journal of Early Years education, 22(1), 59-72. doi: 10.1080/09669760.2013.809656

Hallås, B. O. \& Heggen, M. P. (2018). «We are all nature» - young children's statements about nature. In N. Goga, L. Guanio-Uluru, B. O. Hallås \& A. Nyrnes (Eds.), Ecocritical perspectives on children's texts and cultures (pp. 259-275). Basingstoke: Palgrave Macmillan.

Hatch, J. A. (2010). Rethinking the Relationship Between Learning and Development: Teaching for Learning in Early Childhood Classrooms. The Educational Forum, 74 (3), 258-268. doi: $10.1080 / 00131725.2010 .483911$

Heggen, M. P. (2016). Education for Sustainable Development in Norway. In J. Siraj-Blatchford, C. Mogharreban \& E. Park (Eds.), International Research on Education for Sustainable Development in Early Childhood (pp. 91-102). [Cham, Switzerland], Springer.

Herrington, S. (1998). The garden in Fröbel's kindergarten: beyond the metaphor. Studies in the History of Gardens \& Designed Landscapes, 18(4), 326-338. doi: 10.1080/14601176.1998.10435556

Ideland, M. \& Malmberg, C. (2015). Governing 'eco-certified children' through pastoral power: critical perspectives on education for sustainable development. Environmental Educationa research, 21(2), 173-182. doi: 10.1080/13504622.2013.879696

Ingold, T. (2010). Being alive. Essays on Movement, Knowledge and Description. London and NY: Routledge.

James, A. (2009). Agency. In J. Qvortrup, W. A. Corsaro \& M.-S. Honig (Eds.), The Palgrave Handbook of childhood studies (pp. 34-45). London: Palgrave.

James, A. (2011). To be (come) or not to be (come): Understanding children's citizenship. The annals of the American academy of political and social science, 633(1), 167-179. doi: $10.1177 / 0002716210383642$

Jans, M. (2004). Children as citizens. Childhood, 11(1), 27-44. doi: 10.1177/0907568204040182

Jirout, J. \& Klahr, D. (2012). Children's scientific curiosity: In search of an operational definition of an elusive concept. Developmental Review 32(2), 125-160. doi: 10.1016/j.dr.2012.04.002

Kasin, O., Haugen, A. O., Langholm, G., Heggen, M. P. \& Syed B. F. (2019). Bærekraftig utvikling. Pedagogiske tilnærminger i barnehagen. Bergen: Fagbokforlaget.

Kjørholt, A. T. (2008). Children as new citizens: in the best interests of the child? In A. James \& A. James (Eds.), European childhoods: cultures, politics and childhoods in Europe (pp. s. 14-37). Basingstoke: Palgrave Macmillan.

Klein, J. T. (2014). Interdisciplinary teamwork: the dynamics of collaboration and integration. In S. Derry, C. D. Schunn \& M. A. Gernsbacher (Eds), Interdisciplinary Collaboration: An Emerging Cognitive Science (pp. 23-50). New York: Psychology Press.

Krempig, I. W. \& Utsi, T. Aa. (2017). Hvor kommer maten fra? Høsting av «vill» mat med barnehagen. In B. U. Wilhelmsen (Ed.), Mat- og måltidsaktiviteter i barnehagen. (pp. 81-108). Oslo: Universitetsforlaget.

Langholm, G. (Ed.), Hilmo, I., Holter, K., Lea, A. \& Synnes, K. (2017). Forskerfrøboka. Bergen: Fagbokforlaget.

Lew-Levy, S., Reckin, R., Lavi, N., Cristóbal-Azkarate, J. \& Ellis-Davies, K. (2017). How Do HunterGatherer Children Learn Subsistence Skills? Human Nature, 28,367-394. doi: 10.1007/s12110017-9302-2

Liebel, M. (2008). Citizenship from below: Children's rights and social movements. In A. Invernizzi \& J. Williams (Eds.), Children and citizenship (pp.32-45). London: SAGE Publications Ltd.

Lindholm, M. (2018). Promoting Curiosity? Science \& Education 27(9): 987-1002. doi: 10.1007/ s11191-018-0015-7 
Lister, R. (2003). Citizenship: feminist perspectives. New York: New York University Press. Lister, R. (Ed.) (2008). Unpacking Children's Citizenship. London: Sage Publications Ltd. Łuczaj, Ł., Pieroni, A., Tardío, J., Pardo-de-Santayana, M., Sõukand, R., Svanberg, I. \& Kalle, R. (2012). Wild food plant use in 21st century Europe: the disappearance of old traditions and the search for new cuisines involving wild edibles. Acta Soc Bot Pol, 81(4), 359-370. doi: 10.5586/ asbp.2012.031

Marshall, T. H. (1950). Citizenship and social class and other essays. Cambridge: University Press. Massey, G. \& Bradford, C. (2011). Children as ecocitizens: Ecocriticism and environmental text. In K. Mallan \& C. Bradford (Eds.), Contemporary Children's Literature and film: Engaging with Theory (pp. 109-126). London: Palgrave Macmillan.

Massey, G. (2009). Reading the Environment: Narrative Constructions of Ecological Subjectivities in Australian Children's Literature. (Doctoral Thesis). Queensland University of Technology, Brisbane, Australia.

Massey, G. (2014). Picturing sustainable futures. In K. Mallan (Ed.), Picture books and beyond (pp. 25-40). Newton: Primary English Teaching Association Australia.

McCrea, N. (2015). Food first: Beginning steps towards children's sustainable education. In J. Davis (Ed.), Young children and the environment. Early education for sustainability (pp. 187-208.). Port Melbourne, Vic: Cambrige University Press.

McLennan, D. M. (2010). “Ready, Set, Grow!” Nurturing Young Children Through Gardening. Early Childhood Education Journal, 37(5), 329-333. doi: 10.1007/s10643-009-0366-4

Menning, S. F. (2017). Tracing Curiosity with a Value Perspective. Nordisk tidsskrift for pedagogikk og kritikk 3(1) 1-16. doi: 10.23865/ntpk.v3.531

Midden, K. S. \& Chambers, J. (2000). An evaluation of a childrens garden in developing a greater sensitivity of the environment in preschool children. Hort Technology 1O(2): 385-390.

Miller, D. L. (2007). The Seeds of Learning: Young Children Develop Important Skills Through Their Gardening Activities at a Midwestern Early Education Program. Applied Environmental Education \& Communication, 6(1), 49-66. doi: 10.1080/15330150701318828

Ministry of Climate and Environment. (2016). Friluftsliv- Natur som kilde til helse og livskvalitet (Meld. St.18. 2015-2016). Retrieved from https://www.regjeringen.no/no/dokumenter/meld.st.-18-20152016/id2479100/

Ministry of Education and Research (2005). Lov 2005-06-17 nr. 64: Lov om barnehager (barnehageloven). Retrieved from https://lovdata.no/dokument/NL/lov/2005-06-17-64

Newby, H. (2016). Citizenship in a green world: Global commons and human stewardship.. In M. Bulmer \& A. M. Rees (Eds.), Citizenship today (pp. 209-222). NY: Routledge.

Norwegian Directorate for Education and Training (2017). Frameworkplan for Kindergartens - content and tasks. Retrieved from https://www.udir.no/globalassets/filer/barnehage/rammeplan/ framework-plan-for-kindergartens2-2017.pdf

Nuget, C. \& Beames, S. (2015). Cultural transmission at nature kindergartens: Foraging as key ingredient. Canadian Journal of Environmental Education, 20, 78-91.

Næss, A. (1976). Økologi, samfunn og livstil. Oslo: Universitetsforlaget.

Næss, A. \& Jickling, B. (2000). Deep ecology and education: A conversation with Arne Naess. Canadian Journal of Environmental Education (CJEE), 5(1), 48-62.

Ozer, E. J. (2007). The effects of school gardens on students and schools: conceptualization and considerations for maximizing healthy development. Health Education \& Behavior 34(6), 846863. doi: 10.1177/1090198106289002

Patrick, H. \& Mantzicopoulos, P. (2015) Young Children's Motivation for Learning Science. In K. Trundle K. \& M. Saçkes (Eds.), Research in Early Childhood Science Education (pp.7-34). Dordrecht: Springer.

Robson, E., Bell, S. \& Klocker, N. (2007). Conceptualizing agency in the lives and actions of rural young children. In R. Panelli, S. Punch \& E. Robson (Eds.), Global perspectives on rural childhood and youth. Young rural lives (pp. 135-148). New York/Oxon: Routledge. 
Sageidet, B. M. (2012). Inquirybaserte naturfagaktiviteter i barnehagen. In T. Vist \& M. Alvested (Eds.), Læringskulturer i barnehagen - faglige forskningsperspektiver (pp. 115-139). Oslo: Cappelen Damm Akademisk.

Sageidet, B. M. (2015). Bærekraftig utvikling i barnehagen - bakgrunn og perspektiver. Norsk pedagogisk tidsskrift 99(2), 110-123.

Sageidet, B. M., Almeida, C. \& Dunkley, R. (2018). Children's access to urban gardens in Norway, India and the United Kingdom. International Journal of Environmental and Science Education, 13(5), 467-480.

Samuelsson, I. P. (2011). Why We Should Begin Early with ESD: The Role of Early Childhood Education. International Journal of Early Childhood, 43(2), 103-118. doi: 10.1007/s13158-0110034-X

Seland, M. (2009). Det moderne barn og den fleksible barnehagen. (Doctoral Thesis). NTNU, Norsk Senter for barneforskning, Trondheim.

Siraj-Blatchford, I. (2009). Conceptualising progression in the pedagogy of play and sustained shared thinking in early childhood education: A Vygotskian perspective. Education and Child Psychology 26(2), 77-89.

Siraj-Blatchford, J., Mogharreban, C. \& Park, E. (Eds.). (2016). International research on education for sustainable development in early childhood (Vol. 14). [Cham, Switzerland]: Springer.

Somerville, M. \& Williams, C. (2015). Sustainability education in early childhood: An updated review of research in the field. Contemporary Issues in Early Childhood 16(2), 102-117. doi: $10.1177 / 1463949115585658$

Sundberg, B. \& Ottander C. (2014). Science in preschool - a foundation for education for sustainability. A view from Swedish preschool teacher education. In J. M. Davis \& S. Elliott (Eds.), Research in Early Childhood Education for Sustainability. International perspectives and provocations (pp. 280-293). London: Routledge.

Taylor, A. \& Pacini-Ketchabaw, V. (2015). Learning with children, ants, and worms in the Anthropocene: towards a common world pedagogy of multispecies vulnerability. Pedagogy, Culture \& Society, 23(4), 507-529. doi: 10.1080/14681366.2015.1039050

Thulin, S. (2011). Lærares tal och barnas nyfikenhet: Kommunikasjon om naturvetenskapliga innehåll i førskolen. (Doctoral thesis). Gøteborgs Universitet, Gøteborg.

UNCTAD (2013). Trade and Environment Review 2013. Wake up before it is too late: Make agriculture truly sustainable now for food security in a changing climate. Retrieved from http:// unctad.org/en/pages/PublicationWebflyer.aspx?publicationid $=666$

UNCRC (1989) United Nations General Assembly 44, resolution 25, November, 20th, 1989. Convention on the Right of the Child. Resolution 44/25. Retrieved from http://www.ohchr.org/ Documents/ProfessionalInterest/crc.pdf

UNEP (1975). The Belgrade Charter. Adopted by the UNESCO-UNEP International Environmental Workshop.

UNESCO (2014). Global citizenship education. Preparing learners for the challenges of the 21st century. Retrieved from http://unesdoc.unesco.org/images/0022/002277/227729E.pdf

UNESCO (2015). Transforming our world: the 2030 Agenda for Sustainable Development. Paris: UNESCO.

UNESCO (2017). Education for Sustainable Development Goals. Paris: UNESCO

Utsi, T. Aa., Bøe. K. W. \& Krempig, I. W. (2019). Vill mat i barnehagen - kompetanseutvikling i fellesskap. In V. Bergan \& K. E. W. Bjørndal (Eds.), Bærekraft i praksis i barnehagen (pp. 115-136). Oslo: Universitetsforlaget.

Vadala, C. E., Bixler, R. D. \& James J. J. (2007). Childhood Play and Environmental Interests: Panacea or Snake Oil? The Journal of Environmental Education, 39(1), 3-18. doi: 10.3200/ JOEE.39.1.3-18

van Steenberger, B. (1994). The Condition of Citizenship. London: Sage publishing. 


\section{Heggen et al.}

Vetlesen, A. J. (2015). The Denial of Nature: Environmental Philosophy in the Era of Global Capitalism. NY: Routledge.

Weldemariam, K. (2017). Challenging and expanding the notion of sustainability within early childhood education: Perspectives from post-humanism and/or new materialism. In O. Franck \& C. Osberg (Eds.), Ethical Literacies and Education for Sustainable Development (pp. 105-126). Cham: Palgrave Macmillan.

Wals, A. E. (2012). Shaping the education of tomorrow: 2012 full-length report on the UN decade of education for sustainable development. Paris: UNESCO.

WCED (World Commission on Environment and Development) (1987). Our common future. Report of the world commission on environment and development. New York: UN.

Wiek, A., Withycombe, L. \& Redman, C. L. (2011). Key competencies in sustainability: a reference framework for academic program development. Sustainability Science, 6(2), 203-218. doi: $10.1007 / \mathrm{s} 11625-011-0132-6$

Ødegaard, J. A. (2012). Jannicke Heldal Stray: Demokrati på timeplanen. Tidsskrift for samfunnsforskning, 53(3), 368-371.

Aasen, J. (2006). Tanke og handling - Nøkler til pedagogisk filosofi. Vallset: Opplandske bokforlag

Aasen, W., Grindheim, L. T. \& Waters, J. (2009). The outdoor environment as a site for children's participation, meaning-making and democratic learning: examples from Norwegian kindergartens. Education 3-13: International Journal of Primary, Elementary and Early Years Education 37(1), 5-13. doi: 10.1080/03004270802291749 